\title{
Placement of Political Science Doctoral Students in 1996: Degrees Matter
}

\author{
Sheilah Mann, American Political Science Association
}

This report on the experiences of the 1995-96 political science doctoral students seeking professional placement addresses continuing concerns about the job market. ${ }^{l}$

T erry W. Hartle and Fred Galloway (1996) summarized studies of the academic job market made at the end of the 1980s and in the early 1990s that predicted a demand for faculty would emerge from 1997 to 2002 due to projected increases in the number of undergraduate students and retirement of faculty who earned Ph.D.s into the 1950s and 1960s. Data on the academic job market of the mid 1990s, however, challenge these optimistic predictions. The most recent studies of the supply and demand for science Ph.D.s and M.D.s conclude that there is an oversupply of these professionals. CPST Comments, the journal of the Commission on Professionals in Science and Technology, reports that more young scientists than ever are not able to find permanent jobs (1996b, 3). A note in a later issue of CPST Comments points out that many universities and colleges welcome the retirements of full time faculty as opportunities to make needed budget cuts. In such institutions, the positions held by retiring faculty are eliminated or filled with part-time faculty (1996d, 3).

In their review essay, Hartle and Galloway point out that while recent studies do not estimate the supply and demand for Ph.D.s in social sciences and humanities disciplines, the employment opportunities for these Ph.D.s "would be even more dismal" (1996, 29). However, Hartle and Galloway caution against replacing the earlier optimistic projections of academic job opportunities with a thoroughly pessimistic outlook. They point out that the recent dismal job market projections do not allow for market adjustments, particularly those due to nonacademic employ- ment of Ph.D.s (31-32). They advise that, "Perhaps the most valuable step universities could take is to make certain that potential graduate students have more timely information about employment prospects for recent graduates" (32). Their recommendation should be amended to include advisors in academic programs as well as professional associations. To better inform political science faculty advisors and graduate students about career prospects, APSA collected some additional data on the 1995-96 placement class in its annual survey of Ph.D. departments, and is surveying the members of this placement class about their placement experiences directly. This latter special survey has been made possible through APSA's participation in a multidisciplinary study of the job placement experiences of doctoral students in the sciences and social sciences coordinated by the Commission on Professionals in Science and Technology with funding from the National Science Foundation.

Information presented in this report is based on analysis of the departmental responses to APSA's survey about the placement of 1995-96 political science doctoral students. Findings from the special survey of the students themselves will be reported in a 1998 issue of $P S$ and discussed at the 1998 APSA Annual Meeting in order to determine what increased assistance can be given to doctoral students in their search for employment.

\section{The Placement Class}

APSA has conducted surveys on the employment of political science doctoral students for more than a generation. The current placement survey used e-mail to encourage departments to respond in hopes of assuring a higher response rate, especially from political science de- partments awarding three or more Ph.D.s annually. As a result, while $76 \%$ of all Ph.D. departments responded, $86 \%$ departments awarding an average of three or more degrees annually and $94 \%$ of the departments awarding eight or more degrees annually, submitted reports on their placement classes.

Table 1 is a profile of the 1995-96 placement class. The percentage of women $(29 \%)$ is larger than the previous two years, approaching the highest percentage $(30 \%)$ reported in 1992. The percentages of African Americans (4\%) and Latinos (3\%) in this placement class are the same as in last year's class. This latest survey also asked departments to distinguish among doctoral students seeking employment on the basis of citizenship. As Table 1 shows, $15 \%$ of this placement class are not U.S. citizens. The international composition of political science graduate students is an important characteristic of the profession. An analysis of the placement and career plans of these international students clarifies the pattern of placement in the United States for political science graduates.

Table 1 also shows the percentages of all of the job candidates in major fields of the discipline. While the largest percentage are in American politics, which includes Public Law (29\%), the percentage specializing in comparative politics $(27 \%)$ is nearly the same. Distinguishing between students who are U.S. citizens and those who are not yieldss information about the specializations of political scientists seeking employment, and provides data that a significant proportion of these comparativists are foreign students. Table 2 , on the fields of specialization of international doctoral students, shows that $48 \%$ specialize in comparative politics, accounting for $29 \%$ of the job candidates in the field, and $28 \%$ specialize in international relations, accounting for $17 \%$ of the job candidates in this field. 
TABLE 1.

Profile of 1996 Placement Class, Numbers and (\%), N = 984

\begin{tabular}{|c|c|c|c|}
\hline Citizenship & US Citizens: 834 (85\%) & & Non-US Citizens: $150(15 \%)^{*}$ \\
\hline & $\begin{array}{l}\text { White: } 765(92 \%) \\
\text { Minority: } 69(8 \%) \\
\text { African: } 32(3.8 \%) \\
\text { Latino: } 23(2.8 \%) \\
\text { Asian: } 13(1.6 \%) \\
\text { Native: } \quad 1(0.1 \%)\end{array}$ & & $\begin{array}{l}\text { Permanent Resident: } 34(23 \%) \\
\text { Non-Perm. Resident: } 102(68 \%) \\
\text { NA: } \quad 14(9 \%) \\
\text { * See Appendix } 2 \text { for the list of country o } \\
\text { origin of international candidates. }\end{array}$ \\
\hline Gender & Women: 281 (29\%) & Men: 703 (71\%) & \\
\hline Degree & Ph.D.: 561 (57\%) & ABD: $422(43 \%)$ & NA: $1(0 \%)$ \\
\hline Fields & $\begin{array}{l}\text { Amer. Govt/Public Law: } 282(29 \%) \\
\text { Comparative Politics: } 261(27 \%) \\
\text { International Relations: } 200(20 \%) \\
\text { Political Theory: } 132(13 \%)\end{array}$ & $\begin{array}{l}\text { Public Policy: } 31 \text { (3\%) } \\
\text { Public Administration: } 30 \text { (3\%) } \\
\text { Methodology: } 5 \text { (1\%) } \\
\text { Other: } 36(4 \%) \quad \text { NA: } 7(0 \%)\end{array}$ & \\
\hline
\end{tabular}

The annual "Survey of Doctorate Recipients" conducted by the National Research Council (NRC) collects data on doctorates awarded in all disciplines. Table 3 presents data selected from the most recently published survey of doctorates to profile the 1994-95 class of political science Ph.D.s. The survey of earned Ph.D.s in politics and government in 1994-95 shows that $21 \%$ of the degrees were awarded to non-U.S. citizens holding temporary visas, and $7 \%$ were awarded to non-U.S. citizens with permanent visas. The higher percentage of non-U.S. citizens recorded among actual doctorate recipients than among the later placement candidates suggests that a segment of international student Ph.D.s do not seek employment in

\section{TABLE 2. \\ Percent of the Non U.S. Citizens in the 1995-96 Placement Class by Field}

\begin{tabular}{lc}
\hline American Government & $5 \%$ \\
Public Policy & 5 \\
Comparative Politics & 48 \\
International Relations & 28 \\
Public Administration & 4 \\
Political Theory & 8 \\
Methodology & 1 \\
Other & 2 \\
Total & $101 \%$ * \\
\hline *Does not add up to $100 \%$ due to \\
rounding
\end{tabular}

this country and may not be counted in the APSA placement survey.

Table 4 shows the percentages of non-U.S. doctorate recipients in $\mathrm{cog}$ nate social science disciplines. Sociology and geography also awarded one-fifth of their doctorates to foreign students in 1994-95. Twice as many economics doctorates were earned by foreign students, but under one tenth of the doctorates in anthropology and history were awarded to non-U.S. students. Psychology has the lowest percentage of non-U.S.-citizen degree recipients: $4 \%$.

The percentage of doctorates in all fields of political science awarded to women is similar in 1994-95 to the percentage in the $1995-96$ placement class. The percentage of Ph.D.s awarded to Latinos (recorded by NRC as Mexican Americans and other Hispanics) in political science is the same as for the placement class, but a higher percentage of the degrees in public policy were received by Latinos $(7 \%)$. The NRC reports a higher percentage of black doctoral recipients, $6 \%$, than the $4 \%$ found among graduates seeking employment in 1995-96. Data from the 1994-95 Survey of Earned Doctorates on the median age and time to degree for political science doctorates appear in Appendix 1 of this report.

\section{Placement Success}

The discussion of the outcomes of the search for employment by members of the 1995-96 placement class and of the attributes associated with getting a job begins with an overview of "Trends in Placement" as recorded in Table 5. The 1996 placement class reported on here is larger than the 1995 class. This is true even though fewer departments participated in this year's survey, and is probably attributable to the high response rate among departments with a sizable number of job/candidates/ degree recipients.

An important distinction among members of any placement class is whether or not they sought employment previously. Forty-six percent of the 1996 placement class are repeating a job search. This is the highest percentage of members of a placement class who are "repeats" in the period reported on, 1984-96. Moreover, the percentage of candidates continuing to seek employment increased by $5 \%$ since 1995 and is more than one-third greater than the percentage of "repeats" in 1986-92. Table 5 shows that the percentage of the 1995-96 job candidates who have a Ph.D. is about the same as in the previous year: $57 \%$ in 1996 and $56 \%$ in 1995. However, the percentage of placement candidates with a doctorate is lower in the 1990s than before.

Placement success for the 1995-96 job candidates is compared with that of candidates in previous years in 
TABLE 3.

\section{Characteristics of Doctoral Recipients in all Political Science Fields, 1994-95: Number and (\%)}

\begin{tabular}{|c|c|c|c|c|c|c|c|c|c|c|c|}
\hline \multirow[b]{2}{*}{$\begin{array}{l}\text { Type of } \\
\text { Degree }\end{array}$} & \multirow[b]{2}{*}{$\begin{array}{c}\text { Total } \\
\text { Doctorates }\end{array}$} & \multirow[b]{2}{*}{ Men } & \multirow[b]{2}{*}{ Women } & \multirow{2}{*}{$\begin{array}{c}\text { Non U.S. } \\
\text { Citizens } \\
\text { with } \\
\text { Temp. } \\
\text { Visas }\end{array}$} & \multirow[b]{2}{*}{ Total } & \multicolumn{6}{|c|}{ Ethnicity of U.S. Citizens and Non U.S. Citizens with Perm. Visas } \\
\hline & & & & & & $\begin{array}{l}\text { Am. } \\
\text { India }\end{array}$ & Asian & Black & White & Latino** & Unknown \\
\hline $\begin{array}{l}\text { Political } \\
\text { Science \& } \\
\text { Government }\end{array}$ & 600 & $433(72 \%)$ & $167(28 \%)$ & $126(21 \%)$ & 450 & $1(0 \%)$ & $37(8 \%)$ & $28(6 \%)$ & $367(82 \%)$ & $14(3 \%)$ & $3(1 \%)$ \\
\hline $\begin{array}{c}\text { Public Policy } \\
\text { Analysis }\end{array}$ & 92 & $57(62 \%)$ & $35(38 \%)$ & $11(12 \%)$ & 80 & $0(0 \%)$ & $4(5 \%)$ & $6(8 \%)$ & $64(80 \%)$ & $5(6 \%)$ & $1(1 \%)$ \\
\hline
\end{tabular}

${ }^{*}$ Compiled from Table A-1, p. 105, A-2, p. 108 with \% added. Total is for all individuals with U.S. citizenship and permanent visa status at time of doctorate. Degrees awarded July 1, 1994 through June 30, 1995 as recorded in the 1995 Survey of Earned Doctorates. Henderson, P.H., J.E. Clarke, and M.A. Reynolds. 1996. Summary Report 1995: Doctorate Recipients from United States Universities. Washington, D.C.: National Academy Press. (The report gives the results of data collected in the Survey of Earned Doctorates, sponsored by five federal agencies: NSF, NIH, NEH, U.S. Dept. of Ed., and USDA and conducted by the NRC.) ${ }^{*}$ Mexican American and other Hispanic.

TABLE 4.

Ph.D.s Awarded to Non U.S. Citizens in Social Science Disciplines, 1994-95 (\%)

\begin{tabular}{lr}
\hline Anthropology & $9 \%$ \\
Economics & $42 \%$ \\
Geography & $21 \%$ \\
History & $9 \%$ \\
Political Science & $21 \%$ \\
Psychology & $4 \%$ \\
Sociology & $20 \%$ \\
\hline
\end{tabular}

(Percent of total doctorates in each discipline)

Source: National Research Council, 1996, p. 108.
Table 6. Sixty-four percent of the 1995-96 candidates are employed, the lowest overall percentage in the last decade. In view of the current concern about growth of temporary positions, relative to permanent (tenure track) positions it should be noted that the percentage of all 1996 placements in temporary positions $(29 \%)$ is lower than for 1995 and that the highest percentages of placements in temporary positions were in 1986 and 1988. The percentage of Ph.D.s placed (77\%) is comparable to students' placement success in 1990 and 1992, but less than that in 1995 and 1994 and in the late-1980s.

The sharpest decline in placement success is among ABD students. The percentage of political science ABDs meeting with success in their search for employment (49\%) is the lowest in the decade, albeit just marginally lower than in 1994. The difference in placement success between political science graduates who have Ph.D.s and those who have yet to receive their degrees is persistent over the last three years.

Placement success rates differ overall by gender and ethnicity. Table 6 shows that more of the women graduates seeking jobs were successful $(70 \%)$ than the men $(62 \%)$. Table 7 shows that, among U.S. citizens, a higher percentage of each group of minority doctoral students

TABLE 5.

Trends in Placement

\begin{tabular}{lrrrrrrr}
\hline & 1996 & 1995 & 1994 & 1992 & 1990 & 1988 & 1986 \\
\hline Number of job candidates & 984 & 799 & 1037 & 763 & 823 & 740 & 690 \\
\% repeats & 46 & 41 & 40 & 33 & 32 & 32 & 32 \\
\% Ph.D. & 57 & 56 & 59 & 59 & 59 & 64 & 69 \\
\% women & 29 & 28 & 27 & 30 & 26 & 25 & 26 \\
\hline
\end{tabular}

Note: 1996 figures are from 96 departments (76\% response rate of all Ph.D. programs, $86 \%$ of programs awarding more than an average of three Ph.D.s annually, and $94 \%$ of programs awarding more than an average of eight Ph.D.s annually). 95 departments for 1995 (73\% response rate), 106 departments for 1994 ( $81 \%$ response rate), 110 departments for 1992 ( $87 \%$ response rate), 118 departments for 1990 (93\% response rate), 115 departments for 1988 (92\% response rate), 83 departments for 1986 (70\% response rate), and 83 departments for 1984 ( $71 \%$ response rate). 
TABLE 6.

\section{Placement Success* $(\%)$}

\begin{tabular}{lccccccc}
\hline & 1996 & 1995 & 1994 & 1992 & 1990 & 1988 & 1986 \\
\hline Overall & 65 & 72 & 69 & 74 & 72 & 69 & 69 \\
Ph.D. & 77 & 85 & 82 & 79 & 78 & 83 & 83 \\
ABD & 49 & 56 & 50 & 66 & 63 & 53 & 57 \\
Men & 62 & 72 & 67 & 73 & 73 & 70 & 67 \\
Women & 70 & 71 & 74 & 75 & 70 & 67 & 74 \\
\% placed in temporary positions & 29 & 34 & 29 & 32 & 21 & 38 & 38 \\
Men & 30 & 36 & 29 & 34 & NA & 38 & 38 \\
Women & 26 & 31 & 29 & 28 & NA & 33 & 35 \\
\hline
\end{tabular}

*Placement success measures number placed within each category as a percentage of the total candidates within the respective category. got jobs than did all men and, to a lesser degree of difference, all women. Placement success rates were $77 \%$ for African Americans, $74 \%$ for Latinos, and $83 \%$ for Asian Americans. This overall positive placement record for 1995-96 American minority doctoral students is consistent with the placement experience of their cohorts in the last several years.

Table 7, which has more detail on the relationship between attributes of graduates seeking employment and the outcome of their searches,

\section{TABLE 7.}

\section{Placement Experience of 1995-96 Political Science Doctoral Students by Citizenship, Gender, and Ethnicity (\%)}

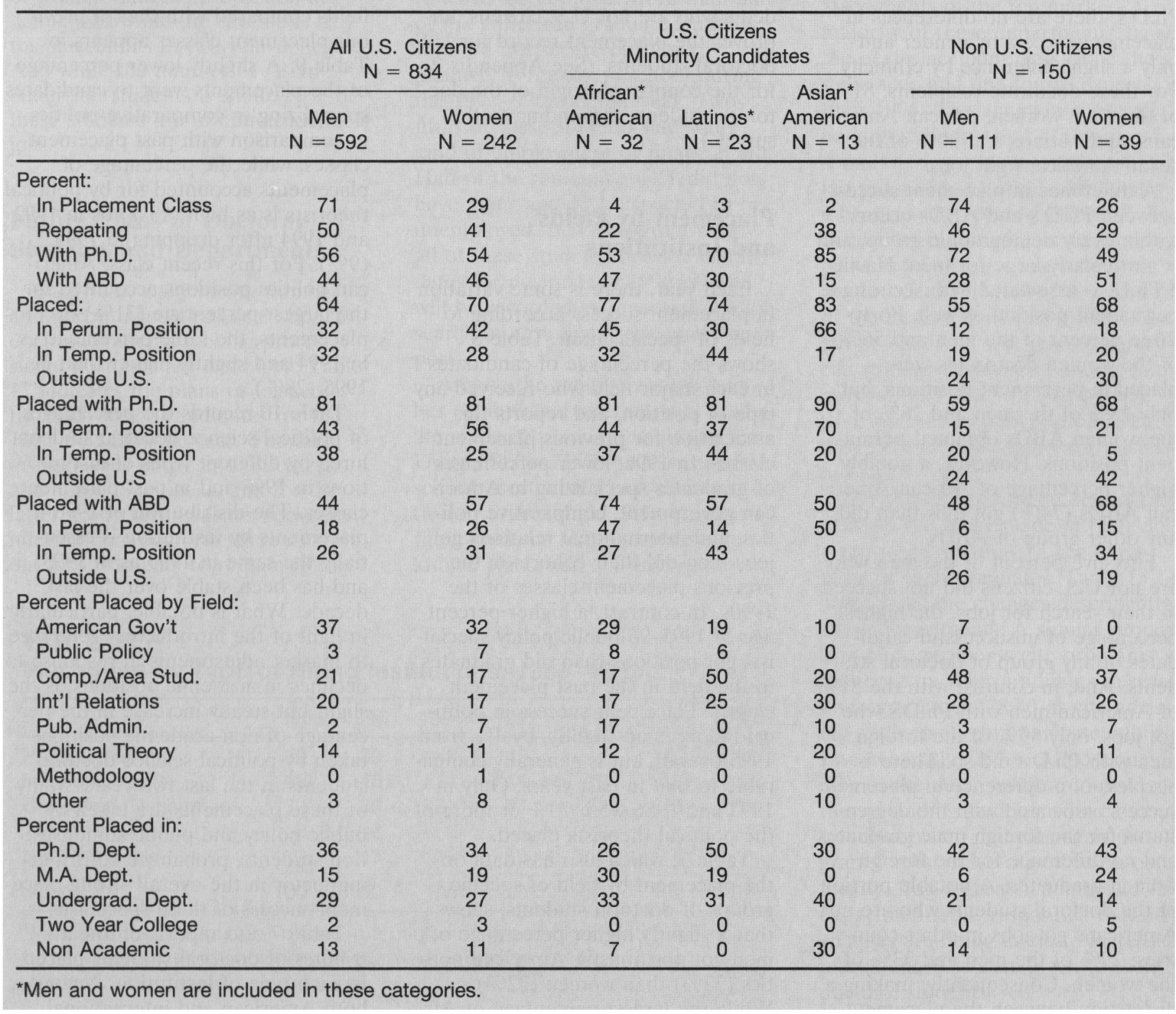


TABLE 8.

Placement Success by Field of Specialization, 1986-96 (\%)*

\begin{tabular}{lccccccr}
\hline & 1996 & 1995 & 1994 & 1992 & 1990 & 1988 & 1986 \\
\hline American Government & 70 & 76 & 74 & 78 & 71 & 74 & 86 \\
Public Policy & 94 & 82 & 80 & 78 & 74 & 82 & 95 \\
Comparative Politics & 57 & 69 & 69 & 77 & 74 & 63 & 65 \\
International Relations & 64 & 73 & 63 & 68 & 71 & 65 & 54 \\
Public Administration & 80 & 86 & 79 & 77 & 74 & 77 & 80 \\
Political Theory & 60 & 56 & 61 & 70 & 61 & 59 & 73 \\
Methodology & 40 & NA & 50 & 50 & 83 & 100 & 100 \\
\hline
\end{tabular}

*Placement success measures number placed within each category as a percentage of the total candidates within the respective category.

shows that degree status is associated with placement success and can be more important than personal attributes. Among U.S. citizens with Ph.D.s, there are no differences in placement success by gender and only a slight difference by ethnicity. For these doctorate recipients, $81 \%$ of the men, women, African Americans, and Latinos and $90 \%$ of the Asian Americans got jobs.

A difference in placement success between Ph.D.s and ABDs occurs within every demographic group, and is particularly large for men. Having a Ph.D. is associated with securing a permanent position as well. Fortythree percent of the men and $56 \%$ of the women doctorates were placed in permanent positions; but only $18 \%$ of the men and $26 \%$ of the women ABDs obtained permanent positions. However, a notably higher percentage of African-American ABDs (74\%) got jobs than did any other group of ABDs.

Fifty-five percent of the men who are not U.S. citizens did not succeed in their search for jobs, the highest percentage of unsuccessful candidates of any group of doctoral students. And, in contrast with the $81 \%$ of American men with Ph.D.s who got jobs, only $59 \%$ of the foreign men with Ph.D.s did so. There is also less of a difference in placement success associated with the degree status for the foreign male graduates and no difference for the foreign women graduates. A notable portion of the doctoral students who are not Americans got jobs in other countries: $29 \%$ of the men and $33 \%$ of the women. Consequently, making a distinction between the placement success of job candidates according to their citizenship status, and accounting for the placement in other countries of a segment of the students who are not U.S. citizens, improves the placement record for U.S. doctoral students. (See Appendix 2 for the country of origin of the doctorate students responding to the survey.)

\section{Placement by Fields and Institutions}

Each year, there is some variation in placement success according to fields of specialization. Table 8 shows the percentage of candidates in each major field who received any type of position, and reports this association for previous placement classes. In 1996, lower percentages of graduates specializing in American government, comparative politics, and international relations got jobs than did their cohorts in the previous placement classes of the 1990 s. In contrast, a higher percentage of 1995-96 public policy specialists got positions than did graduates in the field in the past placement classes. Placement success in political theory is up slightly, by $4 \%$ from 1995 overall, but is generally comparable to that in past years. Only in 1992 and 1986 were $70 \%$ or more of the political theorists placed.

Table 7, which also has data on the placement by field of specific groups of doctoral students, shows that a slightly higher percentage of men got positions in American politics $(37 \%)$ than women $(32 \%)$.

While the largest percentage of Afri-
can-American doctoral students have positions in American politics (29\%), the same percentage $(17 \%)$ have positions in each of the fields of comparative politics, international relations and public administration. A higher percentage of women (7\%), African Americans (8\%), and Latinos $(6 \%)$ are in public policy positions than are men $(3 \%)$. Half of the Asian-American doctoral students have positions in comparative politics and international relations. And, in accord with their stated major fields, $76 \%$ of the men and $63 \%$ of the women graduates who are not U.S. citizens who are placed are in positions in comparative politics or international relations.

Data for the 1995-96 job candidates share of jobs by their major fields compared with that of previous placement classes appears in Table 9. A slightly lower percentage of the placements went to candidates specializing in comparative politics in comparison with past placement classes, while the percentage of placements accounted for by political theorists is as high (13\%) as in 1992 and 1994 after dropping in 1995 $(9 \%)$. For this recent class, American politics positions accounted for the largest percentage $(31 \%)$ of placements, the same percentage as in 1994 and slightly higher than in $1995(28 \%)$.

Table 10 records the percentages of political science doctoral students hired by different types of institutions in 1996 and in past placement classes. The distribution of 1996 placements by institution is essentially the same in 1996 as in 1995 , and has been stable over the last decade. What is notable, particularly in light of the introductory reference to market adjustments in response to declines in academic positions, is the slight but steady increase in the percentage of non-academic positions taken by political science doctoral students in the last two years. Many of these placements are taken by public policy and public administration students, probably a contributing factor in the overall strong placement success of these specialists.

Table 7 also reports on the attributes of doctoral students placed in each type of institution. Among both American and international 
TABLE 9.

Placement by Fields, 1986-96 (\%)*

\begin{tabular}{lrrrrrrr}
\hline & 1996 & 1995 & 1994 & 1992 & 1990 & 1988 & 1986 \\
\hline American Government & 31 & 28 & 31 & 25 & 21 & 23 & 29 \\
Public Policy & 5 & 6 & 5 & 6 & 6 & 6 & 8 \\
Comparative Politics & 23 & 27 & 25 & 27 & 28 & 26 & 25 \\
International Relations & 20 & 24 & 19 & 23 & 25 & 19 & 18 \\
Public Administration & 4 & 5 & 4 & 4 & 5 & 6 & 5 \\
Political Theory & 13 & 9 & 13 & 13 & 10 & 12 & 12 \\
Methodology & 0 & 0 & 0 & 0 & 1 & 2 & 1 \\
Other & 5 & 2 & 3 & 2 & 4 & 7 & 2 \\
\multicolumn{1}{l}{ Total } & 101 & 101 & 100 & 100 & 100 & 101 & 100 \\
\hline
\end{tabular}

*Measures the total number placed from a particular field as a percentage of the total number placed from all fields. May not add up to $100 \%$ due to rounding. students, a slightly lower percentage of women than men took non-academic jobs while the reverse is true for placements in two year colleges. And while the number of AsianAmerican students is small, $30 \%$ of these students are in non-academic jobs.

\section{Future Plans of Doctoral Students and Departments}

Each year, a significant number and percentage of political science doctoral students seeking professional positions are not hired. Table 11 indicates the plans of unsuccessful 1995-96 job candidates for the 1996-97 academic year. The table distinguishes between U.S. citizens and non-U.S. citizens, and for the latter group distinguishes between international doctoral students without jobs who plan to remain in the
United States and those who intend to leave the country. More than half of the American graduate students who did not secure positions planned to remain in school during the 1996-97 academic year. Twofifths of these students had some kind of employment or financial aid. Half of the remaining $44 \%$ did not have plans and $10 \%$ expected to be unemployed. It is likely that nearly all of these students became candidates for positions in 1996-97 and will be recorded as repeating the job search in next year's placement report.

Among the relatively small number of unplaced international graduate students planning to stay in the United States, 35\% plan to stay in school, most with a part-time position or financial aid. Fifty percent of these students had uncertain or unknown plans, and $3 \%$ reported being
TABLE 10.

Placement by Type of Hiring Institutions, 1986-96 (\%)*

\begin{tabular}{|c|c|c|c|c|c|c|c|}
\hline & 1996 & 1995 & 1994 & 1992 & 1990 & 1988 & 1986 \\
\hline Ph.D. Department & 40 & 39 & 42 & 45 & 41 & 40 & 41 \\
\hline MA Department & 16 & 16 & 14 & 11 & 16 & 17 & 16 \\
\hline Undergrad. Department & 29 & 30 & 31 & 31 & 32 & 33 & 32 \\
\hline Two-Year College & 2 & 2 & 2 & 2 & 2 & 2 & 1 \\
\hline Non-Academic & 13 & 13 & 11 & 10 & 10 & 8 & 9 \\
\hline Total & 100 & 100 & 100 & 99 & 101 & 100 & 99 \\
\hline
\end{tabular}

*Measures the total number placed in a particular type of hiring institution as a percentage of the total number placed. May not add up to $100 \%$ due to rounding. unemployed. The majority of these foreign students may also be members of the 1996-97 placement class. On the other hand, many of the foreign students without a job had plans to leave the United States: three-fifths of these students returned to find jobs in their own country; another $11 \%$ will seek an academic job in another country. The employment status of $23 \%$ of the departing foreign students is uncertain.

The Ph.D. departments reporting on the placement of their doctoral students were asked to assess aspects of professional placement and indicate any changes being made to assist graduates in searching for jobs. Table 12 summarizes departmental assessments of the job market. A majority of these departments expect the next placement class to be the same size, and one-fourth expect their 1996-97 placement class will be larger. Nearly half of the responding departments regard current job prospects as comparable to past job prospects. However, $28 \%$ of the departments consider current prospects to be worse, while only $16 \%$ deem them to be better. A plurality of the departments $(40 \%)$ views the job prospects of foreign and American students to be comparable, and most departments $(62 \%)$ believe that interest in non-academic employment is consistent with past interest.

Forty-two departments report that changes are being made in their doctoral programs to assist the placement of their graduates. Table 13 categorizes the changes described by these departments. A similar proportion of departments cite programs that prepare their graduates to teach undergraduates $(28 \%)$ as cite advising students to communicate/publish research early (25\%). Almost onefifth of the departments report either providing students with career information or changing their programs' substantive organization or faculty. But, a greater number of the departments, 51, responded that no changes are being made to increase placement assistance given to their doctoral students. 
TABLE 11.

\section{Plans of 1995-96 Doctoral Candidates Not Placed in U.S. Institutions (\%)*}

\begin{tabular}{|c|c|c|c|c|c|}
\hline \multicolumn{2}{|l|}{$\begin{array}{l}\text { U.S. Candidates Not Placed } \\
\qquad N=278\end{array}$} & \multicolumn{2}{|l|}{$\begin{array}{l}\text { Non U.S. Candidates Who } \\
\text { Plan to Stay in U.S. } \\
\qquad N=37\end{array}$} & \multicolumn{2}{|c|}{$\begin{array}{l}\text { Non U.S. Candidates Who } \\
\text { Plan to Leave/Have Left U.S. } \\
\qquad N=55\end{array}$} \\
\hline $\begin{array}{l}\text { Stay in School with Part Time } \\
\text { position }\end{array}$ & 18 & $\begin{array}{l}\text { Stay in School with Part Time } \\
\text { position }\end{array}$ & 7 & $\begin{array}{l}\text { Return to Own Country for } \\
\text { Academic Job }\end{array}$ & 53 \\
\hline $\begin{array}{l}\text { Stay in School with Financial } \\
\text { Aid }\end{array}$ & 22 & $\begin{array}{l}\text { Stay in School with Financial } \\
\text { Aid }\end{array}$ & 18 & $\begin{array}{l}\text { Return to Own Country for } \\
\text { Non-Academic Job }\end{array}$ & 7 \\
\hline Take Job Outside profession & 13 & Take Job Outside Profession & 11 & $\begin{array}{l}\text { Go to Another Country for } \\
\text { Non-Academic Job }\end{array}$ & 2 \\
\hline Unemployed & 10 & Unemployed & 2 & Unemployed: & 4 \\
\hline Status Uncertain/NA & 21 & Status Uncertain/NA & 58 & Status Uncertain & 23 \\
\hline
\end{tabular}

\section{Conclusion}

A lower percentage of political science doctoral students seeking employment found positions in 1995-96 than students in past years, and a higher percentage of this cohort were repeating the job search than in the past decade. But, fourfifths or more of the Americans who completed their dissertations suc- ceeded in their job searches. Nonetheless, many students were not placed, suggesting that an equivalent or greater number of graduates seeking jobs in 1996-97 will be repeating their job search. But the placement outlook for future political science doctoral students is not totally gloomy.

There are some data that indicate fewer positions were available for the 1995-96 doctoral students. Figure 1 is a graph of the number of first listings in the Association's Personnel Service Newsletter for each of the past three academic years, 1994 97. The graph shows that fewer academic positions were available earlier in the 1995-96 academic year than in the previous year. The num-

\section{TABLE 12.}

Ph.D. Departments' Evaluation of Placement (\%), N = 96

\begin{tabular}{|c|c|c|c|c|c|}
\hline & $\begin{array}{l}\text { Larger } \\
\text { or Better }\end{array}$ & $\begin{array}{l}\text { About } \\
\text { the Same }\end{array}$ & $\begin{array}{l}\text { Smaller } \\
\text { or Worse }\end{array}$ & $\begin{array}{l}\text { Not } \\
\text { Sure }\end{array}$ & NA \\
\hline Expected Size of Next Placement Class & 25 & 54 & 14 & 4 & 3 \\
\hline $\begin{array}{l}\text { Placement Experience of Int'I Candidates Compared } \\
\text { to that of U.S. Candidates }\end{array}$ & 10 & 40 & 15 & 20 & 17 \\
\hline $\begin{array}{l}\text { Interest Showed in Non-Academic Position } \\
\text { Compared to Past Years }\end{array}$ & 13 & 62 & 12 & 9 & 5 \\
\hline
\end{tabular}

*Percentages may not add up to $100 \%$ due to rounding.

TABLE 13.

Changes Being Made in Doctoral Programs to Help Graduates Find Jobs (\%)* N = 42

Teacher training/preparation to teach undergraduate courses

for award competition

*While 42 departments responded that changes are being made, 51 departments are not making changes. 
GRAPH 1-

First Listing In PSN

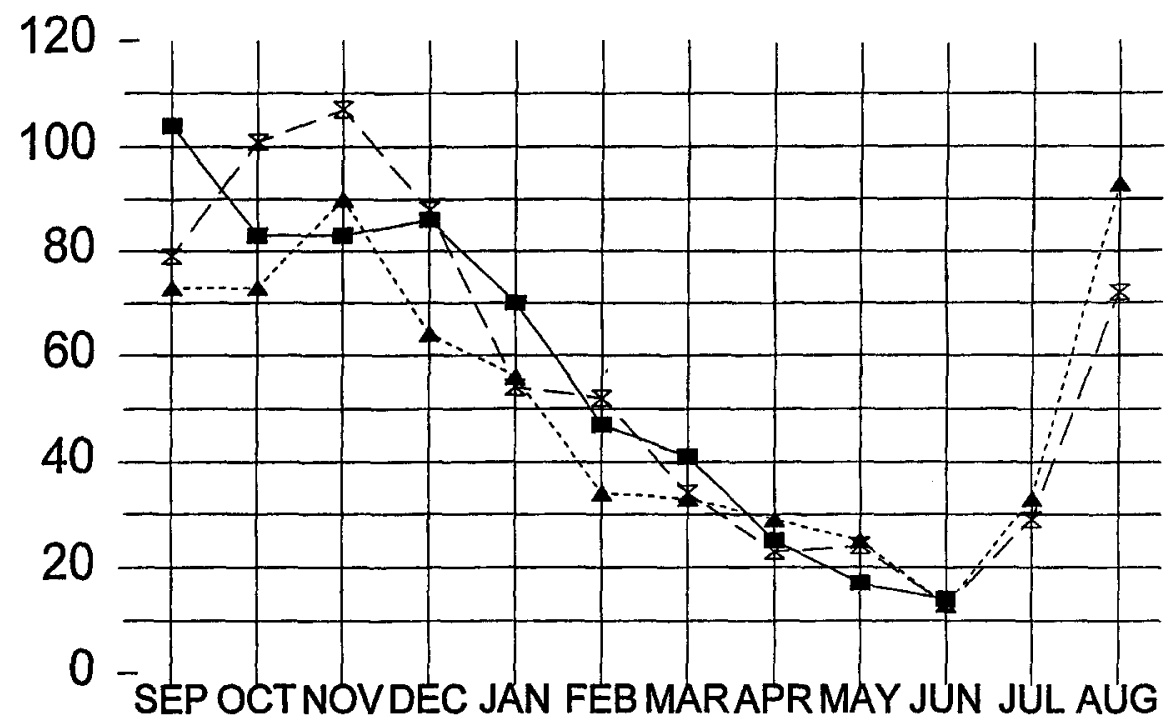

$-1994-95-1995-96-1996-97$
Political science Ph.D. departments and their graduate students could benefit from being informed about the practices of those departments making an effort to prepare doctoral students for the responsibilities of college faculty, in terms of teaching, administrative, professional, and collegial activity, along with scholarship and publishing. Higher education associations, notably the American Association for Higher Education (AAHE) and the Association of American Colleges and Universities (AAC\&U) have projects devoted to teacher training and effectiveness and to preparing future faculty for all of the administrative and professional assignments given them. The 1996 National Academy of Sciences Convocation on Graduate Education (Johnson 1996, Mann 1996) and the report of the Committee on Science, Engineering and Public Policy (COSEPUP 1995) recommended that Ph.D. departments in science, engineering, and social science disciplines include broad professional training in their programs.

A particularly important component of the growth in professional education of future faculty is training that focuses on how to teach undergraduate students. An increasing number of Ph.D. departments are requiring or at least offering doctoral students a seminar course and/or mentored experience to prepare them to teach undergraduate students and increase their marketability, especially to regional universities and public and private colleges. A 1995 survey of Ph.D. departments found that nearly half organized a seminar or course directly or required their students to take a teaching seminar or preparation offered by their university. Sixty-five percent of the political science research departments listed as the "top 20" by the National Research Council's 1995 ranking of doctoral programs responded that they have some teacher training requirement. And, one-third of all Ph.D. departments expected to introduce teacher training or strengthen the preparation already given to doctoral students. Emory University, Syracuse University, and Texas A\&M University are notable, but by no means the only, 
political science departments now including teacher training in their doctoral programs.

The 1998 APSA Annual Meeting will feature sessions on strategies for preparing graduate students to teach undergraduates and assessing the outcomes of such preparation with respect to placement and professional competence. There will also be a separate meeting for graduate and placement directors of Ph.D. programs to discuss professional training and placement in connection with the release of the report on the direct survey of the 1994-95 placement class. Ph.D. department chairpersons, graduate directors, and placement directors are invited to contact the APSA with suggestions for this meeting and to send descriptions of program components devoted to professional education and placement.

\section{Notes}

1. Data entry and tables are by Jun Yin. Polly Leonard and Theresa Gubicza assisted in the preparation of this report.

\section{References}

Brintnall, Michael. 1996. "Job Prospects for Political Scientists: Placement Experience in 1995." PS: Political Science and Politics 29:210-15.

"for the Chair. ..." 1996, 6:4.

"Job Market for Ph.Ds Tight," 1996. CPST Comments 33(3):2-3.

"Job Market for Ph.Ds," 1996b. CPST Comments 33(5): 2-3.

"Supply and Demand," 1996c. CPST Comments 33(7): 1-4.

"for the Chair...," 1996a. CPST Comments 33(6): 4.

Hartle, Terry W., and Fred J. Galloway. 1996. "Too Many Ph.Ds? Too Many M.Ds?" Change 28:27-33.

Henderson, P. H., J. E. Clarke, and M. A. Reynolds. 1996. Summary Report 1995:
Doctorate Recipients form United States Universities. Washington, D.C., National Academy Press.

Johnson, Charles. 1996. "The National Convocation on Science and Engineering Doctoral Education: A Participant's View." PS: Political Science and Politics 29:75455.

Jones, Arnita. 1997. "Memorandum," January 22.

Mann, Sheilah. 1996. "Two-Year College Political Science Faculty: Recruitment and Responsibilities." PS: Political Science and Politics 29:94-95.

—_. 1996. "Addressing Career Needs of
Future Ph.Ds." PS: Political Science and Politics 29:754.

National Research Council. 1996. Survey of Earned Doctorates. Washington, DC: National Academy Press.

"Reshaping the Graduate Education of Scientists and Engineers," 1995. COSEPUP. Washington, D.C., National Academy Press.

\section{APPENDIX 1. \\ Median Age and Time to Degree for Doctoral Recipients in Political Science/International Relations*}

\begin{tabular}{lr}
\hline Median Age at Doctorate & $33.9 \mathrm{yrs}$ \\
Percent with BA in Field & $51.6 \%$ \\
Percent with Masters & $83.8 \%$ \\
Median Time Lapse from & \\
$\quad$ Baccalaureate to & \\
Doctorate & $10.8 \mathrm{yrs}$ \\
Total Time & $7.9 \mathrm{yrs}$ \\
Registered Time & \\
\hline
\end{tabular}

*Source: NRC 1996, p. 111.

\section{APPENDIX 2. Country of Origin of all Non U.S. Placement Candidates, $\mathbf{N}=150$}

\begin{tabular}{lc}
\hline \multicolumn{1}{c}{ Country, N $=41$} & $\mathrm{~N}$ \\
\hline Korea & 22 \\
China, India & $12^{\star}$ \\
Canada, England & $11^{*}$ \\
Taiwan & 10 \\
Russia & 5 \\
Mexico, Saudi Arabia & $4^{\star}$ \\
Australia, Japan, Poland, South Africa, Switzerland, Turkey & $3^{\star}$ \\
Bangladesh, Belgium, Cameron, Egypt, France, Germany, Italy, & $2^{\star}$ \\
$\quad$ Lebanon, Malaysia, Nigeria & $1^{*}$ \\
Algeria, Brazil, Cyprus, Ethiopia, Iraq, Jordan, Morocco, Netherlands, & \\
Pakistan, Philippines, Spain, Sri Lanka, Sweden, Uruguay, Venezuela, & \\
\hline
\end{tabular}

*Same number of candidates for each country. 